\title{
Scottish Lettering of the 16th century
}

\section{Aidan Harrison ${ }^{1}$ and Charles J Burnett ${ }^{2}$}

\begin{abstract}
Surviving visual culture from the early modern period that can be described as particularly Scottish in style is scarce. As a result, any evidence of such artistry is of national significance. The purpose of this article is to draw attention to a form of lettering which was used for the display of short inscriptions and initials in Scotland throughout the 16th century. Surviving examples are almost exclusively carved in relief in durable wood and stone.

This distinctive letterform is drawn from the transitional styles which briefly appeared at the end of the 15th century as French artists and scribes transferred their allegiance from their traditional ornate Gothic capitals to the bold, simple Roman forms of the Renaissance. While a number of experimental letterforms fleetingly appeared elsewhere across northern Europe, Scottish scholars absorbed these new influences in France and developed them into a distinctive form which persisted in Scotland for over a century.

After its first known appearance at the marriage of King James IV to Margaret Tudor in Edinburgh in 1503, the evidence suggests that the use of Scottish Lettering became confined to Aberdeen and the north-east, primarily in pre-Reformation ecclesiastical applications. Following the Reformation, it became largely restricted to secular and funerary inscriptions.
\end{abstract}

\section{INTRODUCTION}

The objective of this study is to draw the attention of scholars of Scottish history and its art to an element of the nation's sparse cultural material remaining from the 16 th century which has largely been overlooked: its lettering. The predominant physical evidence of the era lies in the ruins of Scotland's castles, churches and abbeys whose destruction has not only left the nation without the original tombs of its kings and queens, but many of the more subtle cultural symbols which help to define a nation's identity. This exploration of the lettering of the period argues that, despite its grand beginnings at the court of King James IV, the letterform discussed here has received surprisingly little attention in the existing literature and as a result has been forgotten as a significant emblem of Scottish identity. Thomson's study of Scottish tombstone inscriptions features two examples, one on an original grave-slab of 1577 at Dundee and a 20thcentury reproduction at King's College Chapel, Old Aberdeen. The letterform is described as 'archaic Roman capitals' (Thomson 2009: 73).

Five centuries after its first usage, the few survivals of this letterform are today confined to initials and brief inscriptions carved in oak and stone, with some of the latter severely eroded. It is almost invariably carved in the skilled, costly and relatively rare 'raised' or 'relief' form in which the background is cut back to leave the letters prominent. For the sake of clarity it will be referred to here as 'Scottish Lettering'.

This letterform appeared in Scotland amidst wider cultural influences introduced by Aberdeen's Catholic scholars around the end of the 15 th century. It adds to the evidence of an early Scottish Renaissance which later English and Protestant Scottish historians sought to deny because it did not match their preferred image of pre-Reformation Scotland as superstitious,

\footnotetext{
1 aidanharrison4@gmail.com
}

2 charles@rossherald.co.uk 
backward and barbaric. The persistence of this lettering in the Catholic stronghold of the north-east is therefore significant (Stevenson \& Davidson 2009: 3/20; Thomas 2013: 1-11).

Amongst the earliest instances of Renaissanceinfluenced visual culture in the British Isles, the origins of this letterform are likely to date back to Scottish scholars who studied and taught in late 15th-century France. Its distinguishing features evidently evolved from a range of fleeting stylistic experiments as French scribes made the transition from their familiar decorated medieval Gothic letterforms to the reintroduction of classical Roman letters - which was central to the rediscovered art and design of the Italian Renaissance as it swept north across Europe. The evidence presented here suggests that after its initial appearance at the court of King James IV, a specific combination of these experimental elements was united into a consistent form which endured in north-east Scotland for a century (see Illus 1).

The principal characteristics of Scottish Lettering in its purest form are:

- Concave sides to the broad verticals, forming wide, flat upper and lower serifs

- Plain central indents or 'bites' to the wide serifs, as opposed to 'splits' or 'fishtails'

- Narrow diagonals, with a half-height ' $v$ ' to the centre of ' $M$ '

- A mid-height 'dot' to the verticals.

The absence of a corresponding minuscule, or 'lower case' alphabet, shows that this letterform was devised for display rather than as a book-hand and was limited to short inscriptions and initials. In medieval society where literacy was restricted to a small fraction of the population, manuscripts, texts and documents written in Latin were only for the eyes of scholars, priests, lawyers and the educated ruling class. As a result, the display of single initials, words or brief mottoes was to a large degree the only lettering accessible to most citizens, often incorporated with the more complex symbolism of, for example, a coat of arms. Conveying a message, whether of identity, piety or power to the uneducated majority could be aided by providing the letterform with a striking, recognisable shape within its artistic and physical context (Ross 2014: 35). Because their design was therefore so important, considerable effort was expended on creating distinctive styles such as the highly decorated 'historiated' introductory letter of a manuscript page, which might help the observer associate it with a familiar religious passage, or the single bold initial on a coat of arms helped to identify it with a noble personage. It is therefore fitting that the first recorded appearance of Scottish Lettering was at one of the most important, yet uncharacteristically peaceful and optimistic moments in the nation's history: the marriage of King James IV and Margaret Tudor at Holyrood Abbey, Edinburgh, on 8 August 1503.

The next known survival of this innovative letterform is in a further regal commission; on James IV's coat of arms displayed on the newly completed King's College Chapel, Old Aberdeen, and dated a year later at 1504. The remaining evidence suggests that, despite such a
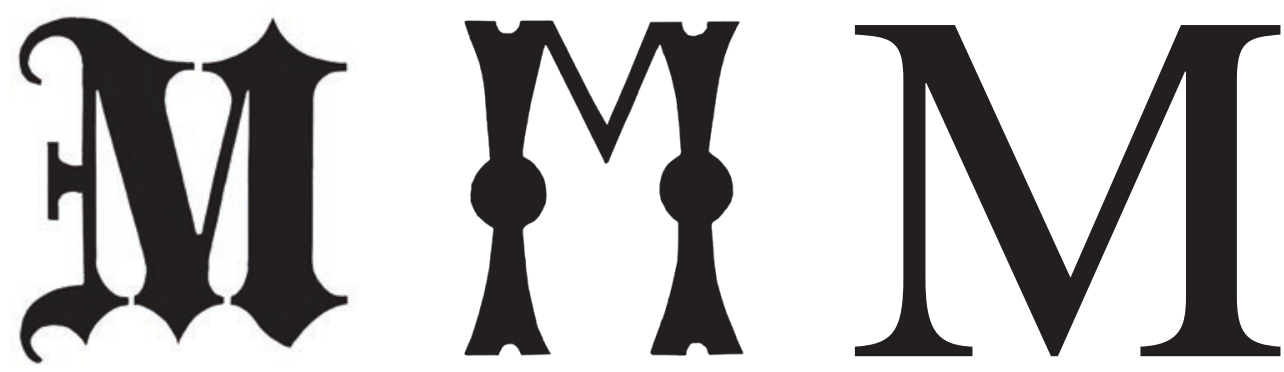

ILLus 1 Gothic, Scottish and Roman capital letter 'M' compared. (C) Aidan Harrison 
prestigious initial appearance, Scottish Lettering then became confined to the north-east, where it continued in use until the end of the century. In contrast, the rest of Scotland, including the west and the Northern Isles, stayed faithful to the traditional Gothic lettering until its direct replacement by the classical Roman style around the time of the Scottish Reformation in 1560-70 (Richardson 1927: 390; Higgitt 1988: 10-11). Explanations for this apparent restriction of Scottish Lettering to the north-east so soon after its introduction are therefore also explored.

The transition from Gothic writing to the fully developed Roman form in France on the cusp between the 15 th and 16 th centuries is outlined, along with some of Scotland's scholars who may have been involved in the emergence of a specific letterform. Sixteen examples of Scottish Lettering are then discussed in chronological order and its persistence throughout an entire century is evaluated.

\section{FRENCH ORIGINS}

Early in the 15 th century, Italian Renaissance humanist scholars such as Poggio Bracciolini (1380-1459) began to explore the rediscovered Romanesque letterforms of 600-year-old writings from the reign of Charlemagne (Pflughaupt 2007: 22-3). This resulted in experiments with hybrid Gothic/Roman forms of capitals with tapering and wedge serifs (Gray 1986: 1235). Later French artists such as Jean Fouquet (1420-81) returned home from Italy to further test their discoveries. They continued to write text in the traditional Gothic minuscule lettering, restricting their new styles to the capitals in short inscriptions on haloes, on banners and in frames within their paintings and miniatures (Gray 1986: 135). Gray describes the development of a new style as follows:

Sometimes it seems to be just a question of using one or two non-Roman forms; sometimes of wayward self-expression; and sometimes a real style is achieved $^{*}$. Typical letters are 'A' with a cross-bar across the apex, or perhaps a broken cross-bar; ' $G$ ' is round, not spurred, and sometimes ' $D$ '. The sides of ' $M$ ' are straight and heavy, the diagonals thin; 'M' has a short-ranging ' $\mathrm{v}$ '... Terminations are often wedge-shaped, sometimes with a bite out of the base; there may also be a bite or a bulge in the middle of the stem (Gray 1986: 148).

(*emphasis by current authors)

Printer Thielman Kerver produced a large quantity of Books of Hours in Paris between 1497 and 1520. His choice for setting out the manuscript pages in his various editions varied between Gothic letters for north European markets and the Roman form for south European countries. However, one feature which remained consistent was his trademark frontispiece. It displays his name on a banner at the bottom, surmounted by a device bearing his initials, which is supported by a pair of unicorns. Kerver's decorated print block demonstrates the contemporary influences from France on the development of Scottish Lettering (see Illus 2). Illustrations from both Kerver's 1503 Book of Hours and his earlier Sarum Hours were adopted for ecclesiastical wood carvings in Scotland, namely the 'devil with mermaid' and 'piping pig' panels from Fetteresso Church, near Aberdeen, of 1510-20 and the Annunciation scene on the Beaton panels of $c 1530$ at the National Museum of Scotland. Further examples of similar letterforms from Paris are likely to have also found their way to Scotland with returning scholars. While these passing styles typically faded from use on the Continent in the space of a decade or two as the classical Roman form swiftly replaced them, the evidence shows that Scotland's particular form endured for a century.

\section{SCOTTISH LETTERING}

The acquisition of religious texts was important to the Scottish scholars studying and teaching in France because most of them were churchmen. For instance, William Elphinstone (1431-1514) was not only Bishop of Aberdeen and founder of its university, but also Chancellor of Scotland in 1488 and Keeper of the Privy Seal. He had earlier been a student at the University of Paris in 1469, before becoming a lecturer at the University of Orléans and then returning to Aberdeen in 1473. His years at the centre of French learning 


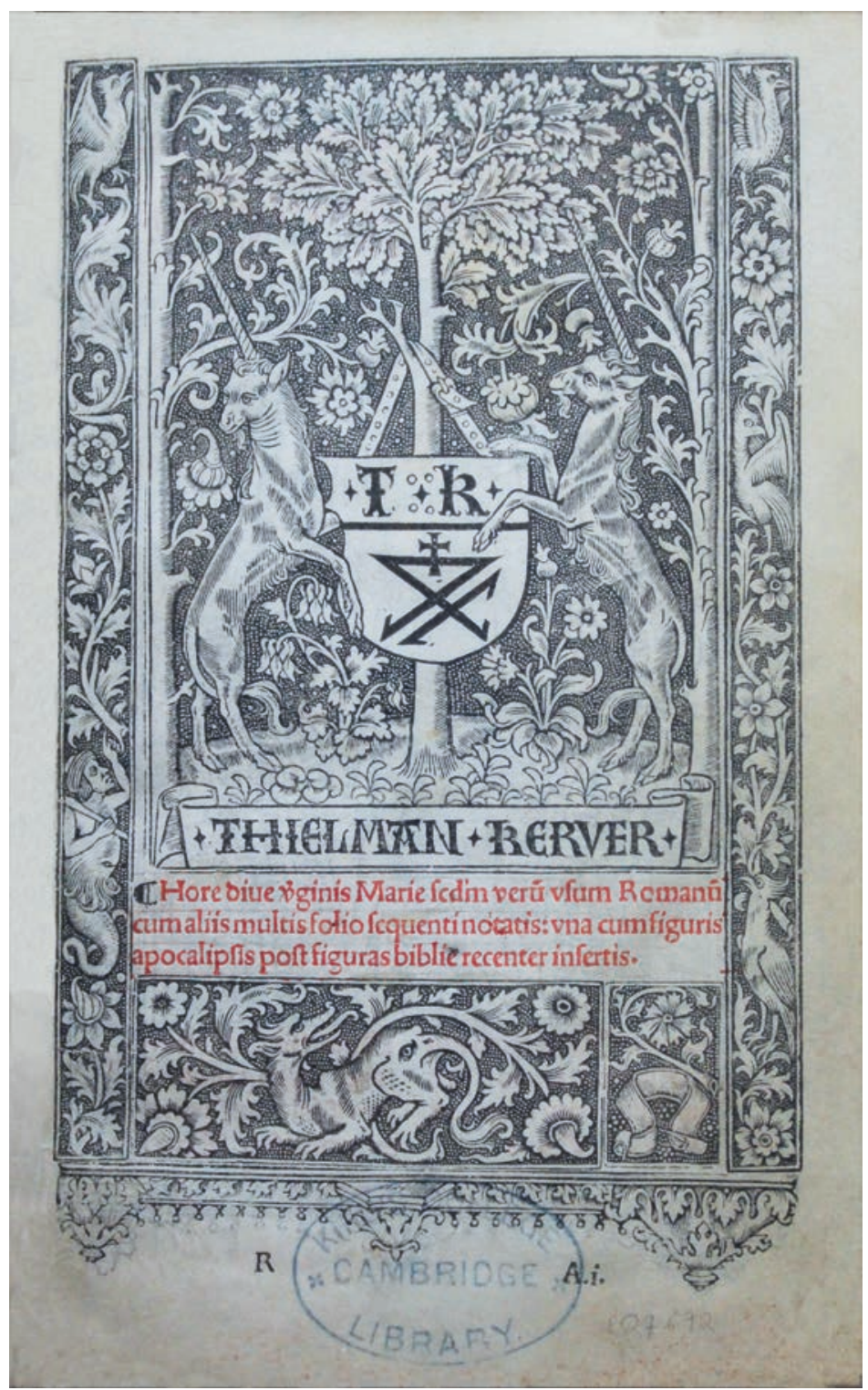

Illus 2 Example of lettering from Thielman Kerver Book of Hours. (C) By permission of the Provost and Scholars of King's College, Cambridge

coincided with a number of artists that included Jean Fouquet who was experimenting in Paris with letterforms in, for example, his Hours of Etienne Chevalier (Gray 1986: 135). A slighter later and equally renowned Scottish scholar was Dundee-born Hector Boece (c 1465-1536) who not only studied but also taught at the University of Paris. In 1500 this friend of Erasmus was persuaded to return to King's College, Old Aberdeen, as its first principal where he worked closely with William Elphinstone and, as a result, almost inevitably with the bishop's colleague, 
Alexander Galloway, whose enduring devotion to Scottish Lettering is discussed later. The degree of French scholarly and artistic influence on Scotland is exemplified by the books printed in recorded Scottish libraries up to 1560: well over 500 were produced in France, but only five in England (Simpson 2009: 16).

\section{THE MARRIAGE OF KING JAMES IV TO MARGARET TUDOR}

The first known application of Scottish Lettering was at the highest level. After centuries of conflict between England and Scotland, the marriage of King James IV to Margaret Tudor, elder daughter of King Henry VII, was seen by both nations as a means of finally cementing a peace treaty. Several years of negotiations between members of the nobility at the courts of James IV and Henry VII, under the guidance of prominent English and Scottish clerics, resulted in the Ratification of the Marriage Contract between King James IV and Margaret Tudor and the Treaty of Perpetual Peace. Both were signed and exchanged in 1502 at a proxy wedding at Richmond Palace, prior to the approval of Pope Alexander VI in May 1503. The formal marriage between the two royal families of the British Isles took place the following August in Edinburgh. The expense lavished on the wedding and the Scottish king's enthusiasm for the latest fashion and art in celebrating the occasion are well documented (Paul 1901). As cultural innovations in medieval Europe almost invariably made their initial appearance at court, the adoption of a novel form of lettering for this historic event, devised from the latest artistic developments from Scotland's great ally, France, was fitting (MacDonald 2003: 169-70; Thomas 2013: 17).

\section{EDINBURGH 1502-3: ARTEFACTS FROM THE ROYAL MARRIAGE}

Throughout the 16th century the letter 'I' was also used to signify 'J'. Four surviving objects associated with the marriage of 1503 bear the monogram of James IV and Margaret Tudor: 'I\&M'. Three of them display the royal initials in Scottish Lettering and are likely to have been made in Scotland while the fourth uses a different letterform because it is the work of Flemish artists.

\section{EXAMPLE 1: THE MARRIAGE DOCUMENT}

Due to their reflection of national status and the importance of both a peace treaty and a royal marriage between former long-standing foes, each nation produced the appropriate documents to the highest possible standards in design and materials. These masterpieces in vellum were decorated with gold leaf and the most exotic pigments available, including vermilion reds, malachite greens and azurite blues and decorated with silver thread and wild silk from India (Rosie \& Ramsay 2001-2: 65-6).

Of the documents made in England, only the peace treaty survives (NAS SP6/31). It has a finely executed border of red Tudor roses and foliage by an unrecorded artist. The text begins with a large decorated or 'historiated' initial ' $h$ ' and '(h)enricus dei gratia rex angliae ...' entirely written in the Gothic lettering familiar in England at the time.

The Scottish documents are recorded as being painted by Thomas Galbraith. An artist of standing who enjoyed royal patronage, he is also recorded as illuminating works for the Chapel Royal: the Gospels in 1507-8 and a breviary in 1511-12 (Macmillan 2000: 31). The Scottish version of the peace treaty (PRO E39/58) is in poor condition having lost much of its detail and colour and is written entirely in Gothic lettering. His major recorded artistic accomplishments suggest that Galbraith, a clerk at the Chapel Royal at Stirling, was fully capable of adopting a combination of stylistic features from Paris including, for example, Kerver's printed frontispiece and other contemporary French artists, to produce a new and distinct Scottish Lettering. While there is no record of Galbraith travelling to France, he was well placed to be influenced by the prominent clerics who studied and taught in Paris and travelled widely throughout the Continent. 


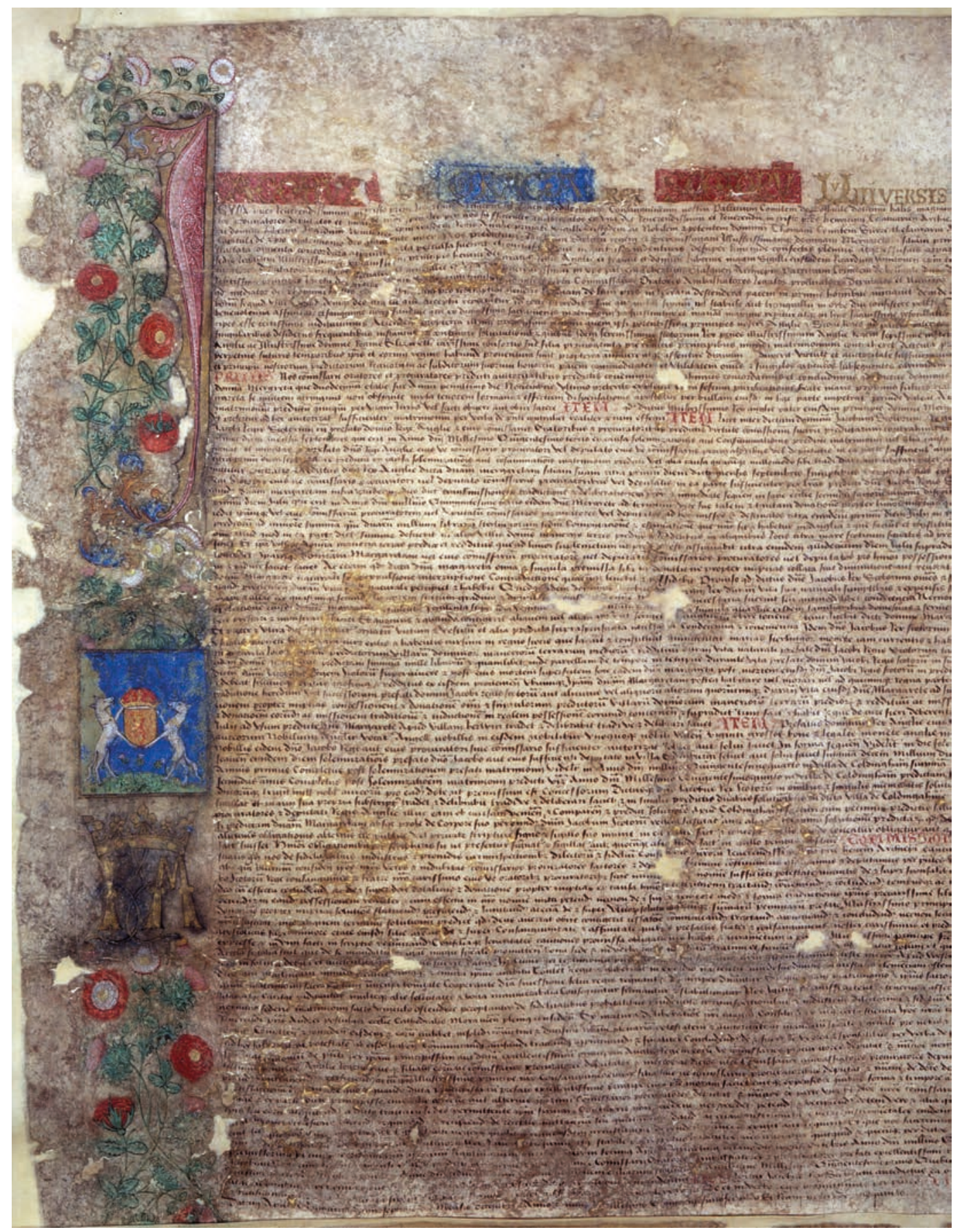

ILLus 3 Ratification document of the Marriage of James IV and Margaret Tudor. (C) The National Archives (E39/81) 
The evidence that this Lettering was derived by Scottish churchmen from artistic influences originating in France can be seen in the marriage document (PRO E39/81). It is in better condition, decorated by Galbraith with finely executed and coloured thistles, roses and marguerites representing Scotland, England and the new Queen Margaret (see Illus 3). Of particular relevance to this study, the first line in gold lettering begins, like the English peace treaty, with a bold historiated Gothic 'I' and the first words identically over-painted in red and blue. However, while the form of words is the same '(I)ACOBUS DEI GRATIA REX SCOTORUM ...' the first line of this marriage document differs from that on the English document. Instead of the Gothic form, with the exception of the first letter it is written in the new capitals from France. Elsewhere in the text, which is otherwise in Gothic minuscule, is the word 'COMMISSION' and, heading each section of the text, the word 'ITEM' is also written in the same form.

The most significant feature of Galbraith's marriage document here is that it also

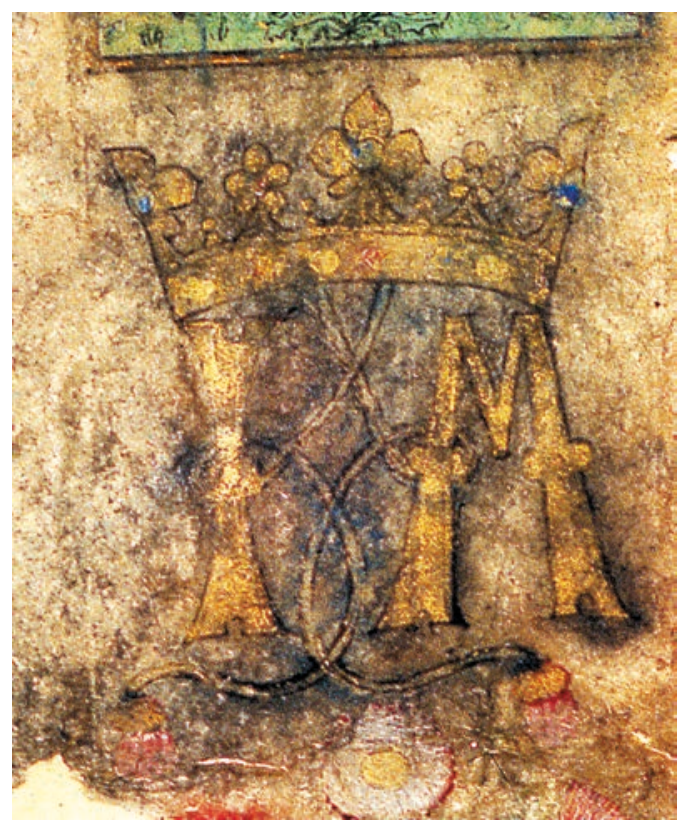

ILLus 4 Detail showing monogram on Ratification Document. (C) The National Archives (E39/81) incorporates a bold monogram, its content showing that it was devised especially for this great occasion. In comparison with the finely handwritten capitals heading the document, it has two large initials 'I' (for James) and ' $M$ ' (for Margaret) painted in a much more formal and considered form: 'I\&M' (see Illus 4). This is the first known example of Scottish Lettering. The initials are conjoined by a flowing 'love knot' which, instead of the tassels featured in similar monograms of the Gothic period to celebrate the union of highstatus couples, terminates in Scottish thistles. The golden monogram is surmounted by a golden coronet, with the verticals of the letter ' $M$ ' inclined inwards so that the coronet can be accommodated in an aesthetically satisfactory manner. After almost 300 years of Gothic writing, the introduction of this new lettering on such an internationally important document was surely intended to visually convey a symbolic statement of a modern, forward-looking Scottish royal identity to both the English and Scottish witnesses of this pivotal marriage contract, which both united the Tudors to the Stewarts and formalised the peace between Scotland and England.

\section{EXAMPLE 2: THE FLOOR TILE AT LINLITHGOW PALACE}

Linlithgow Palace, along with its lands, was among the marriage gifts from James to his queen. A single intact tile remains from the floor of what is believed to have been the king's presence chamber. It bears the royal 'I\&M' monogram of the marriage document, its rather crudely moulded form of Scottish Lettering suggesting that it is of local manufacture (Norton 1994: 137-73). Little else remains of the fine interior decoration at Linlithgow Palace following the fire of 1746, so this James IV tile provides the rare opportunity to contrast the use of this type of monogram, a symbol retained from the Gothic era, with the fully developed Renaissance style of the famous carved oak roundel heads displayed on the ceiling of the equivalent presence chamber of his son, James V, at Stirling Castle just 30 years later. 


\section{EXAMPLE 3: THE MARRIAGE CHEST}

Surviving furniture of the Gothic period is scarce. Specimens bearing a personal, secular identity are almost unknown and indicate highstatus ownership. Sophisticated joined-frame and panelled construction at this early date, together with fine carved 'linenfold' panels to its sides, emphasise the prestige of this chest at the National Museum of Scotland (Harrison 2012 (accession no. NMS; IL.2015.10)) (see Illus 5). The left-hand front panel of this marriage chest is finely carved with the ' $I \& M$ ' monogram in the same Scottish Lettering used on the wedding document. The only other known example of this Gothic form of monogram on a surviving piece of furniture is that painted in gold on the cradle of 1478-9 at the National Museum in Brussels, which shows the similar 'love-knot' linked 'M\&M' initials of the future Holy Roman Emperor, Maximilian of Austria and his wife, Mary of Burgundy, but using a different letterform (Eames 1977: pls 34a-b; Thirion 1999: 61). A further feature of the chest's design that suggests a likely Scottish origin lies in the ' $S$ '-profile or 'double-ogee' moulding surrounding its panels, which is in precisely the same form evident in all of the surviving framed oak panelling attributed to the Aberdeen workshop of John Fendour. This consistent profile points to its use as a 'signature in wood' in the specific shape left by Fendour's own moulding tools, just as stonemasons are believed to have created distinctive 'signature' moulding on pillars and door and window surrounds with their personal wooden templates (Fawcett 2013: 46). Fendour's moulding is also of the same profile used in contemporary Scottish stonework, suggesting that he may have copied his style from masonry with which he was familiar (Fawcett 2013: 55).

The chest's right-hand panel is decorated with the small, exquisitely carved quatrefoil flowers also associated with the work of Fendour (Kelly 1934: 365; Simpson 1949: 65). Despite adopting this new Scottish Lettering and the most up-to-date framed and panelled methods

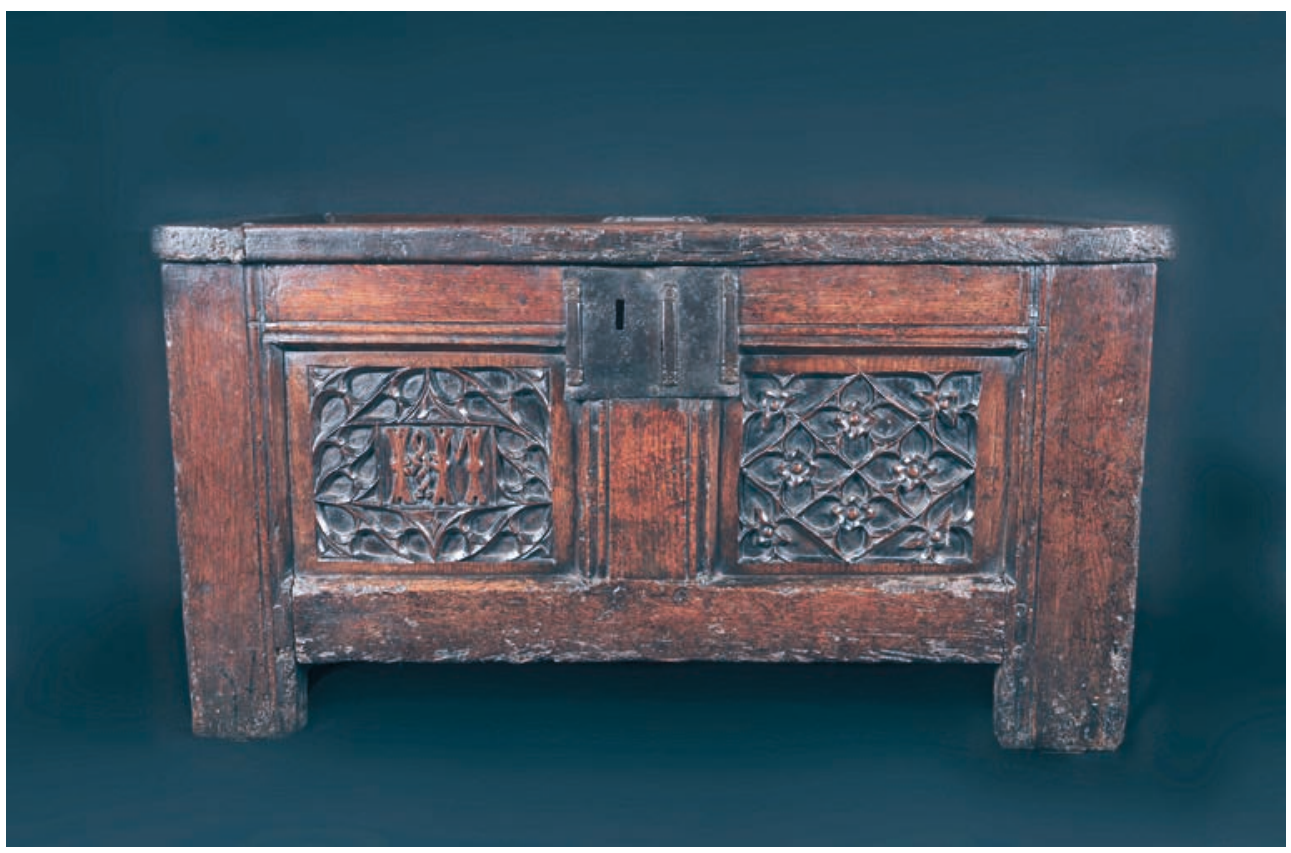

ILlus 5 Marriage chest believed to be that of James IV and Margaret Tudor. NMS; IL. 2015.10. Reproduced with permission of Graham Wade 
of construction, Fendour persisted, perhaps because of his isolation at Aberdeen, with his 'flamboyant' Gothic carved oak decoration after it had become obsolete elsewhere.

Further examples of the royal monogram appear in the The Vienna Hours, a personal gift from James to his bride (Anon 1897: fl 14v). The particular relevance of the Book of Hours to this essay is that, while it displays the 'I\&M' monogram, the initials are not in Scottish Lettering because the manuscript is Flemish (Smeyers 1999: 466-7; Kren \& McKendrick 2003: 366, 414). The artists must have seen drawings of the designs for the king's coat of arms, his motto and the marriage monogram for the appropriate pages when the manuscript was commissioned. The fact that the artists of The Vienna Hours used their own Flemish style of lettering indicates that, even in a manuscript produced for the King of Scots, Scottish Lettering was the prerogative of native artists and craftsmen. A number of Flemish artists briefly adopted this naturalistic letterform at the turn of the 15th and 16th centuries; more ornate than the Scottish style, it was therefore better suited to painting than carving. It treated individual letters as though they were twigs and branches, decorated with notches to the 'stems', sometimes with diagonally 'pruned' terminations and even sprouting leaves. This pruned tree-like form is still known in heraldry as 'raguly' where it features in the Burgundian white saltire on a red field because at the time Flanders came under the rule of Burgundy.

\section{EXAMPLE 4: KING JAMES IV'S HERALDIC STONE PANEL AT HOLYROOD PALACE}

Amongst the expenses lavished on his wedding, James IV spent a considerable sum on extending his Edinburgh Palace of Holyroodhouse. During intervening reigns the building has been so dramatically altered that little of his original palace remains. In 1503 a new gatehouse was constructed, with his Royal Arms and 'IRS' for 'James King of Scots' above the entrance (Dunbar 1999: 59). This large heraldic carved stone is recorded in The Accounts as having been painted by Thomas Galbraith, who had previously decorated the marriage documents.
Its lettering acknowledges the new Scottish form but the profile is narrower, perhaps because of its unfamiliarity to the unrecorded stonemason. Its outline has been further blurred by later applications of gold paint. This stone is today built into the wall of the Abbey Strand. Its use in differing media on the few survivals from the marriage raises the likelihood that the 'I\&M' marriage monogram in Scottish Lettering appeared more widely on the hundreds of objects and regalia, including textiles purchased for the occasion which are listed over 42 pages in The Accounts under 'Pro Rege et Regina' (Paul 1901).

\section{SCOTTISH LETTERING IN THE NORTH- EAST 1504-1604}

After its initial appearance in connection with the royal marriage, surviving examples of Scottish Lettering suggest that it was largely restricted to carving in stone and wood for the display of initials and short inscriptions in north-east Scotland.

\section{EXAMPLE 5: THE ARMS OF KING JAMES IV: KING'S COLLEGE CHAPEL}

James IV is known to have made regular visits to inspect the new college at Old Aberdeen during its construction, in collaboration with Bishop William Elphinstone, its founder. The king's coat of arms on the building's façade bears two inscriptions in Scottish Lettering; the first, at the top, reads 'ANNO DNI 1504', an exceptionally early use of Arabic numerals in the British Isles. The scroll below this, with the earliest dated version of the royal arms in Scotland, reads 'IN DEFENS', a shortened version of the original: 'IN MY DEFENS GOD US DEFEND' (Burnett 2014: 164). Higgitt comments on the lettering;

inscribed in an early sixteenth-century type of nonclassical capital that is embellished with 'bites' into the top and bottom of verticals and with knob-like protruberances (Higgitt 2014: 68).

It makes a dramatic contrast with the foundation inscription at eye level on the 
same façade, which records the beginning of construction in April 1500 and is entirely carved in Gothic minuscule lettering (Higgitt 2014: 66). The Gothic script at eye level with which students and educated visitors of the period were familiar contrasts with the innovative and elite use of the striking new Scottish Lettering, together with the early use of Arabic numerals for the 1504 date, carved on the king's coat of arms high overhead.

\section{JOHN FENDOUR: ABERDEEN'S MASTER-}

CRAFTSMAN IN OAK

John Fendour's adoption of Scottish Lettering on the marriage chest believed to be that of James IV and Margaret Tudor, discussed on $\mathrm{p} 226$, and his further use of the letterform along with his other 'trademarks', which are seen on the remnants of his work at Aberdeen, warrants further exploration. His remaining carved oak panels within their original framing are today at King's College Chapel and in the undercroft chapel of St Nicholas Kirk, while his panel from the city's Royal Mint is at the Marischal Museum.

Little is known of Fendour's origins. While both Flemish and French connections have been discussed, his name suggests that he was French. $\mathrm{He}$ is recorded as undertaking major contracts for both Church and Crown between 1495 and around 1520 , indicating that he already ran an established and reputable workshop in Aberdeen at the earlier date (Simpson 2014: 88-91). Two of his decorative 'trademarks', the late use of flamboyant Gothic tracery and small carved fourleaved flowers date back to France a generation or two earlier, where many examples of both can be found. This suggests the possibility that Fendour may have served his apprenticeship or worked in a leading French workshop before settling in Scotland. By the time he was working in Aberdeen, however, fine woodcarving in France was moving on from Gothic tracery to Renaissance designs, along with the adoption of Roman lettering.

There has been some debate over the origins of the woodwork at King's College Chapel. It is accepted that the rood-screen, its doors and 'ambo' are all Fendour's work, but that some elements of the choir-stalls may have originated from different sources at different times (Simpson 2014: 8093). The only carved lettering is on three of the surviving misericords. One displays the 'IhS' or 'In hoc Signo' symbol in raised Scottish lettering, the ' $h$ ' untypical in that it is lower case. The other lettering is on the smaller 'boy's' misericords. That to the south side of the chapel entrance displays a fine carved crown, beneath which is a complex monogram of overlaid capitals, of similar size to the 'IhS' letters, again carved in relief. MacCannell describes this monogram as being open to a range of interpretations because one of the letters could either be an ' $\mathrm{O}$ ' or a circular ' $\mathrm{m}$ ' similar to that on the font from Kinkell Church which is discussed on p 230 (MacCannell 2014: 95-8). The boy's misericord to the south of the chapel entrance depicting the arms of William Elphinstone is something of an anomaly. The carving differs not only from the other misericords, but from the rest of the woodwork in that it is relatively shallow and, while bold, it is comparatively unsophisticated. It lacks the lily pot, lily branches and interlaced fish usually associated with Elphinstone. The bishop's mitre is excessively large, the chevron distorted and there is a large variation in the size of the three Elphinstone boars' heads. Taken together with the fact that its lettering is all in the Gothic form, some of it small and incised, it is unlikely that this misericord is Fendour's work.

\section{Example 6: The Elphinstone Heraldic Panel at King's College Chapel}

While its original position within the building is unclear, this oak panel is today mounted high on the north wall inside the chapel, displaying the arms of the founder of the college, Bishop William Elphinstone, with his motto 'NON CONFVDAR' carved in Scottish Lettering. It is described as being Fendour's work, with particular attention drawn to the small four-leaved flowers typical of his work (Simpson 1949: 65).

\section{Example 7: King James V's Heraldic Panel from Aberdeen Royal Mint}

The latest known example of Fendour's lettering at Aberdeen is the oak heraldic panel which is now at the university's Marischal Museum. It is understood to be from the city's Royal Mint 


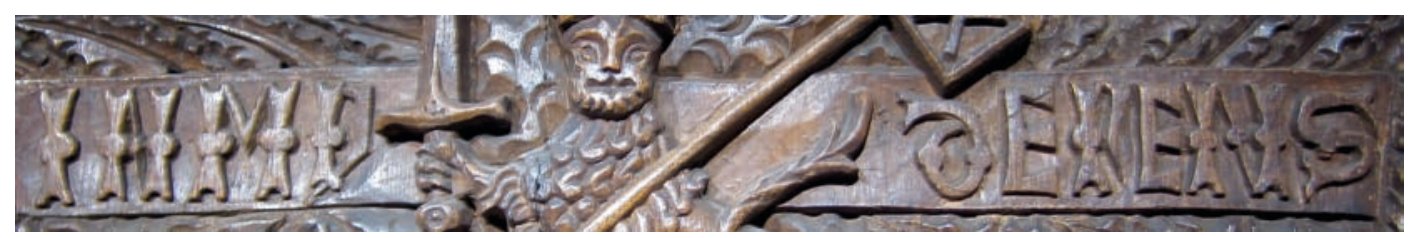

ILlus 6 Inscription detail; Oak Armorial panel from Aberdeen Royal Mint. Marischal Museum. (C) Aidan Harrison

and is dated to $c 1520$ because it bears the coat of arms of the young King James V. It is unusual in that the unicorn supporters are reguardant, a form unique to north-east Scotland. Carved in relief in Scottish Lettering is the royal motto, 'IN MY DEFENS', while below are the initials of William Roland, 'VR', master of the royal mint, all carved in Scottish Lettering in Fendour's distinctive raised or 'relief' form (see Illus 6). The panel is framed by his characteristic moulding profile.

\section{Example 8: The Fetteresso Panels}

The oak panels from Fetteresso Church, near Stonehaven, dating from 1510-20, are believed to be originally from a pulpit but, having spent many intervening years incorporated into a secular cupboard, are unfortunately orphaned from their original moulded framing. Despite the missing extra evidence which the framing might have provided, they are likely to be the work of Fendour, with two of them bearing inscriptions in Scottish Lettering. As discussed on p 221, their decoration demonstrates contemporary French influences on early 16th-century Scottish artistic styles (Geddes 2016: 168-73).

The records of John Fendour's work and the surviving evidence suggest that 25 years may well have marked the span of his Aberdeen career. It is, however, likely that it overlapped with that of another prominent local craftsman, master-mason Thomas French whose father is believed to have brought the family trade from France.

\section{EXAMPLE 9: THE ORIGINAL CARVED HERALDRY ON THE BRIDGE OF DEE}

With its seven 50-foot arches, the Bridge of Dee, two miles west of Aberdeen, formed the only southern approach to the city for centuries. It began with a bequest of $£ 20,000$ from Bishop William Elphinstone in 1514. Its construction continued under Bishop Gavin Dunbar with the project overseen by a further Aberdeen cleric, Alexander Galloway, while the master-mason was Thomas French. The original bridge was completed in 1529 , then extensively restructured in 1719-24, while its entire western face was removed and then replaced when it was widened in 1840. These operations have left the bridge with many inscribed commemorative stones from three different centuries. Those relevant to this study mark the original work of Thomas French during the 1520s. Writing in 1913, local historian G M Fraser found that after four centuries of exposure to Aberdeen's weather, these stones were considerably eroded, with some completely illegible and others barely readable. As the century since Fraser's study has inevitably worsened the erosion, some reliance must be placed on his observations. A number of the date-blocks above the coats of arms display dates between 1520 and 1527 as the construction progressed from south to north. Some of them include 'ANO DNI' in Scottish Lettering. Those associated stones which were more legible in 1913 include the initials 'GD' for Gavin Dunbar and 'VE' for William Elphinstone. One of the latter included the bishop's motto 'NON CONFUNDAR', as already discussed at King's College Chapel and described here as 'carved in raised Scottish capitals’ (Fraser 1913: 27). This is the only known written reference to Scottish Lettering which names it as a specific style.

\section{ALEXANDER GALLOWAY AND THOMAS FRENCH}

While Thomas Galbraith of Stirling is likely to have been the first to deploy this letterform in 
his painted royal marriage document and the Holyrood Palace heraldry, a higher ranking cleric, Alexander Galloway (c 1480-1552), appears to have been responsible for keeping Scottish Lettering alive in the Aberdeen diocese, where he was an influential figure until his death shortly before the Reformation. Among the earliest students at King's College, he was an eyewitness to its construction while in his mid-20s, when the coat of arms of King James IV carved with the radical new lettering was installed on its façade. This observation may have influenced his attachment to the letterform. A friend and ally of Bishop William Elphinstone, he was not only a lawyer and notary but an academic with connections to continental scholars (Campbell 2014: 160; Holmes 2015: 62). Galloway also supervised further building projects including two successive manses, Greyfriars Church and a number of small churches across the Aberdeen diocese. Because of the large amount of such construction at this time, he is very likely to have worked with John Fendour, and was closely involved with Thomas French on building the Bridge of Dee until its completion in 1529 (Simpson 1949: 24).

\section{Example 10: Kinkell sacrament house}

In 1524 Alexander Galloway completed the church of St Michael at Kinkell, near Inverurie, where he was rector at the time. In the ruins of the church is the earliest of north-east Scotland's sacrament houses. This is inscribed with Galloway's initials in Scottish Lettering. In view of their collaboration on the Bridge of Dee and the shared letterform, it appears likely that the work was carried out by Thomas French. Galloway's personal attachment to the use of this lettering is suggested by the limitation of the surviving ecclesiastical examples both to his diocese and his own lifetime.

The Scottish sacrament house consisted of a built-in cupboard or aumbry within the north wall of the church, gifted by a wealthy donor and, in place of the pyx suspended over the altar in English churches for the same purpose, intended to ensure the safety of the sacrament. It was usually augmented by carved stone decoration and inscriptions, often displaying the initials of the donor and the date. Heal (2003: 101) reports that least 35 medieval churches have sacrament houses or aumbrys in them, at least half of which date from after 1500. It appears likely that sacrament houses were installed to promote devotion to the Catholic tradition at a time when the Reformation was making inroads into southern Scotland (Oram 2016: 27).

Many sacrament houses were in Scotland's north-east, but most of those that remain are in roofless ruins, making it inevitable that they have suffered weathering to their vulnerable carvings. Despite having been fitted with glass and concrete shelters and roofs for protection from the northern climate, some lettering is now only legible in photographs taken in the 19th century. The inscriptions at Kinkell are seriously weathered, but some of the Scottish Lettering is still visible today, incised on a scroll, along with Galloway's initials and the date 1524. Nearby is a bronze replacement of a crucifixion scene moulded from the original eroded stone in 1933. Also in relief it bears the date 1525, along with his initials 'AG' and 'INRI' in the same lettering. The latter restoration is believed to have been carried out by William Kelly, whose choice of Scottish Lettering for further restoration and reproduction in important roles at Aberdeen is discussed later. The original font from Kinkell Church is now in the Episcopal church of $\mathrm{St}$ John the Evangelist in Aberdeen. Its carving of Galloway's initials 'AG' is identical to that in the ruined church, but, safe from weathering, it is still crisp. On its opposite face is carved a capital ' $M$ ' in a similar rounded form to that on the King's College Chapel misericord already mentioned on p 228. It is noteworthy that Alexander Galloway's two initials 'AG', like those of William Roland, 'VR' on the royal mint panel of similar 1520 s date which is described on $\mathrm{p} 229$, are conjoined. Both examples show that craftsmen briefly but incongruously aped the logical earlier practise of linking the single initials of a couple of the highest status in a 'love knot', as in the 'I\&M' monogram for James IV and Margaret Tudor.

\section{Example 11: Auchindoir sacrament house}

Much farther from Aberdeen, in the ruin of the church of St Mary at Auchindoir (Canmore 


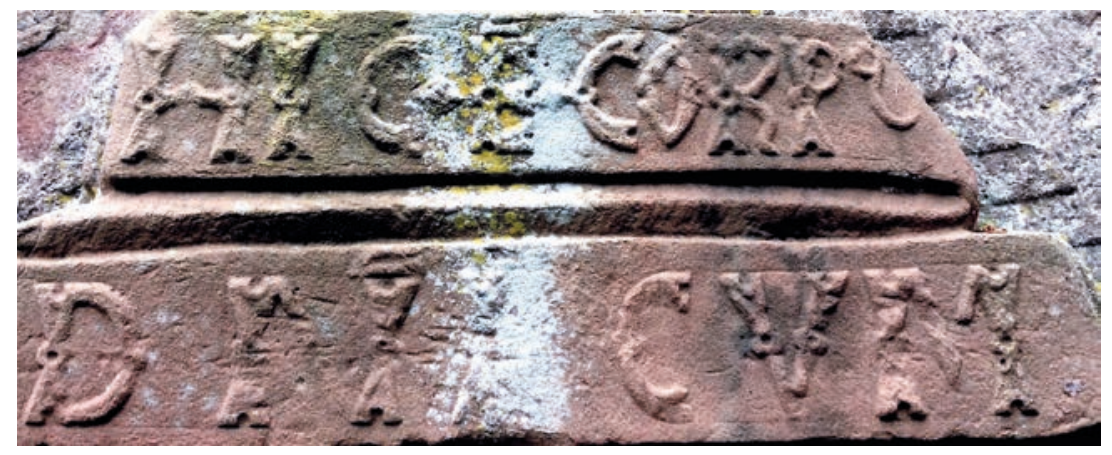

ILLus 7 Inscription on sacrament house, St Mary's Church, Auchindoir, Rhynie, Aberdeenshire. (C) Aidan Harrison

ID 17230), the initials of Alexander Spittal, a colleague of Galloway and a prebendary at King's College Chapel, Aberdeen, are carved in relief on its sacrament house in Scottish Lettering. In the same form the Latin inscription reads (in translation) 'THIS IS THE LORD'S BODY' (see Illus 7).

Alexander Galloway's initials and the date 1544 inscribed on the sill are all that remain on the sacrament house at the ruined chapel at Dyce, while he may also have been responsible for that at Kintore, which today bears neither date nor identity (Fawcett 2013: 261-2).

It is possible that Scottish Lettering continued to be used in various media at court throughout the decade-long reign of James IV and Queen Margaret but little such evidence of the flourishing Scottish art and culture recorded under their rule has survived. Major architectural endeavours were revived for a further relatively brief period between James $\mathrm{V}$ finally attaining independent power in 1528 and his death in 1542. Along with his two successive French queens, the young king indulged his love of the new Renaissance styles of art in all their forms, as exemplified by his enlargement and enhancement of his father's palaces at Holyrood, Stirling, Linlithgow and Falkland. With the notable exception of Thomas French, the work appears to have been executed by immigrant French craftsmen, including the masons sent by the king's in-laws, the Duke and Duchess of Guise (Fawcett 1994: 320).
The evidence of lettering during the reign of James $\mathrm{V}$ is scarce because most has been destroyed or, like the original heraldry in lead on his tower built between 1528 and 1532 at the Palace of Holyroodhouse, has been substituted with misleading replacements, leaving it impossible to know their original form. The presence of his initials 'AG' carved in relief in Scottish Lettering on a number of the later works commissioned by Galloway suggests that this was the result of his continuing influence on the masons remaining from French's workshop after the latter had been summoned to work at Linlithgow Palace in 1535 (Simpson 1949: 27).

\section{EXAMPLE 12: THE GATEHOUSE TO LINLITHGOW PALACE}

Scottish Lettering is used on the four panels displaying the Orders of Chivalry bestowed on James $\mathrm{V}$ over his outer gatehouse at Linlithgow Palace. They show the Scottish Thistle, the English Garter, the Burgundian Golden Fleece and the French Order of St Michael. Due to the particular scarcity of surviving inscriptions of any form outside the Aberdeen diocese during this reign, these inscriptions are noteworthy. Each panel displays a lengthy scroll whose sinuous Latin motto is carved to a very high standard (see Illus 8). The presence of the letterform on this clearly important royal commission so far from its 


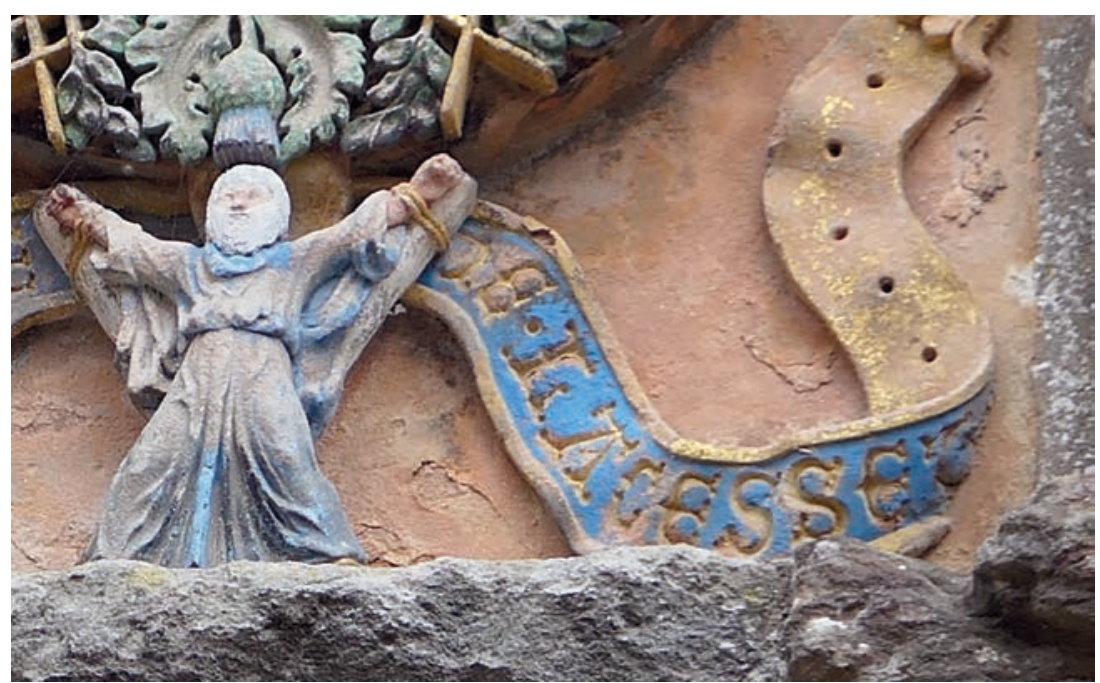

ILLus 8 Inscription detail; James V Order of Chivalry, outer gatehouse at Linlithgow Palace. (C) Aidan Harrison

known contemporary usage in the north-east is something of an anomaly. While it raises the possibility that Scottish Lettering was more widespread in central Scotland but that the rest of the evidence has been destroyed, a more likely explanation for its use in these inscriptions carved in 1535-6 is the presence of Thomas French, who built this gatehouse after arriving from Aberdeen to work at the palace (Fawcett 1994: 325). As his legacy in the north-east shows, Scottish Lettering was French's trademark and it appears significant that James V, famous as a Renaissance king, was apparently not averse to the use of this lettering from his father's era on this proud display of his international status over his new palace gate. French evidently made an impression because he was then appointed as the king's master-mason for life before continuing with further work at both Holyrood and Falkland palaces. The lack of inscriptions leaves it impossible to know what style of lettering, if any, was employed on those later commissions. (Dunbar 1999: 227). Although the Linlithgow panels saw major restoration around 1850 , a near contemporary account emphasises confidence in their fundamental originality: 'they are not copies but are very close to the original designs' (Waldie 1868: 40).

\section{EXAMPLE 13: CULLEN OLD KIRK AND DESKFORD} SACRAMENT HOUSES

Cullen Old Kirk (Canmore ID 17965) contains a wealth of carved stone decoration and lettering from the mid-1500s, which straddles Gothic and Renaissance styles. Most spectacular is the 1544 tomb of Alexander Ogilvie and his wife Elizabeth Gordon. Above the dramatic crocketed Gothic arch containing the figural effigy of a knight are a pair of Renaissance roundels displaying portraits of husband and wife. Behind the reclining knight is an incised inscription in Gothic script. Alongside the tomb is the sacrament house donated by Alexander and Elizabeth. Above the two supporting angels holding aloft a monstrance is an unusually long Latin inscription in raised Scottish Lettering (see Illus 9). From John 6:55, it translates as: 'My flesh is meat indeed, and my blood is drink indeed: He that eateth my flesh and drinketh my blood, shall live forever' (Swarbrick 2016: 132).

At the nearby ruins of Deskford Church is an almost identical sacrament house, apparently made by the same mason and commissioned by the same Alexander Ogilvie and Elizabeth Gordon, along with the date 1551. It has been suggested that Alexander Galloway was 


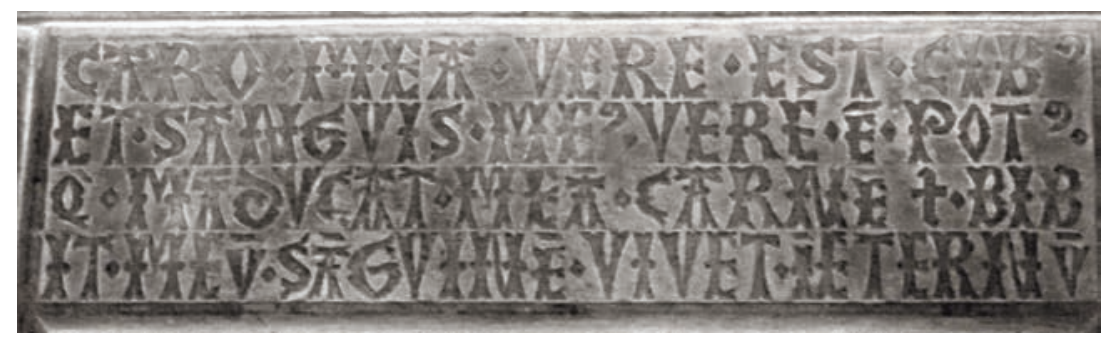

Illus 9 Inscription detail; sacrament house in Cullen Old Church, Cullen, Moray. (C) Aidan Harrison

involved in the design of both of these late sacrament houses (Holmes 2015: 207). Apart from their initials carved in relief, there are also incised scrolls in Scottish Lettering beneath their respective coats of arms below the aumbry. Immediately above is a lengthy inscription in an equally late use of Gothic lettering to that on their tomb at Cullen. It is noteworthy that in its rare application in the incised form, these later examples of Scottish Lettering at Deskford and Cullen are inevitably much less striking than those carved in relief.

On the exterior north wall of Cullen Old Kirk are three separate heraldic stones, each carved in relief, with the initials in Scottish Lettering: 'IO' for James Ogilvie (d 1509), 'IO' for his younger son (also James, who predeceased him in 1505) and 'AO' for his eldest son Alexander Ogilvie (d 1554). They are identical in form, suggesting that all three were installed at the later date, at the time of the construction of the great tomb within this small church and, coincidentally, just after the death of Alexander Galloway.

Cullen Old Kirk also holds a rare and apparently isolated example of a transition towards more fully developed raised Roman lettering from this period in the north-east. In St Anne's aisle these letters have broad verticals, some of which are concave but others are tapered, while the notched serifs and the midheight 'dots' of the pure Scottish Lettering are lacking. The name of the mason, John Moir, is included in one of his inscriptions executed in 1536-9 (Swarbrick 2016: 126-30). No further work by Moir is recorded in Scotland.

\section{ABERDEEN AND THE NORTH-EAST - BASTION OF CATHOLIC SCOTLAND}

The grandeur of Bishop William Elphinstone's original tomb at Aberdeen demonstrates the enduring power of the Catholic Church in north-east Scotland in the first half of the 16th century (Campbell 2014: 149-60). As a result of both the late date of the Scottish Reformation and Aberdeen's isolation, the construction, improvement and decoration of church structures, such as the sacrament houses, evidently persisted right up to the religious revolution. Aberdeen, its university and surrounding regions, remote from the risk of the English invasions suffered farther south, was largely separated from the turmoil in central Scotland by the barrier of hills and marshlands known as 'The Mounth'. These physical limitations on inland travel are highlighted by the fact that Aberdeen's third most important maritime link was with Dundee, just 60 miles away. Shipping records emphasise the city's face to mainland Europe for its primary trading links with the Flemish ports, Dieppe, Danzig and Norway (Dennison et al 2002: 387). In its geographical, spiritual and cultural isolation, Aberdeen appears to have assumed the role of the last bastion of Roman Catholic worship and learning in Scotland. During such challenging times the remnants of his sacrament houses and their inscriptions suggest that Alexander Galloway not only defended Scotland's old faith, but also its associated visual culture in the northeast until his death in 1552. Inevitably, however, the new forms of worship brought an end to the need of religious decoration and inscriptions. By 
the beginning of the 17 th century, the classical Roman form had finally replaced Scottish Lettering. It is possible that Scottish Lettering may also have been initially shunned because of its Catholic associations.

\section{LATER SCOTTISH LETTERING}

\section{LETTERING CARVED IN WOOD AFTER FENDOUR}

Examples of Scottish Lettering in woodwork that are later than John Fendour's period are scarce. Among those few are the 16th-century oak stalls and canopies at Dunblane Cathedral. One misericord is carved in relief, 'GRACIA DEI', and another, 'MARIA', in a rather more ornate style than Fendour's. Their framing also lacks his distinctive mouldings and 'fleurons'. The surrounding carved decoration shows Renaissance influences, suggesting that they date from late in Bishop James Chisholm's tenure of 1487-1526 and may have been carved by a Flemish or French craftsman (Simpson 2014: 84). Its application raises the possibility that the letterform was particularly requested by Chisholm.

A set of three panels, whose current whereabouts, or indeed survival, is unknown, apart from Small's drawing, depict the Arms of Margaret Stewart, the illegitimate daughter of James IV and Margaret Drummond, and her second husband, Sir John Drummond of Innerpeffray, dated 1530. Likely to have come from a chest, one of the panels displays Scottish Lettering (Small 1878: pl 90).

It is impossible to discuss Scottish woodwork of the period without touching on the famous c 1530 Beaton panels at the National Museum of Scotland. Despite lacking the evidence that their original framing might have provided, their decoration is very different in style to that of John Fendour's workshop and it has been suggested that they may be the work of French wright Andrew Mansion (d 1579), employing designs such as the Annunciation scene from Thielman Kerver's work (see p 221) (McRoberts \& Holmes 2012: 73-7). The Gothic lettering on the Beaton panel contrasts with Fendour's raised Scottish form.
The latest remnant of the dwindling influence of Scottish Lettering discovered to date in wood is the initials, 'IO', of Janet Ogilvy, wife of Sir William Forbes of Tolquhon, carved in relief beneath her father's arms on an oak Aberdeenmade chair dating from 1596-7. The 'I' (J) for Janet has all of the characteristics of the Scottish letterform apart from the missing 'bites' or incisions to the flat serifs. The ' $\mathrm{O}$ ' for Ogilvy is in the appropriate 'pointed' form (Harrison 2015: 3 ). Evidence that this is a late remnant of Scottish Lettering is clear in the near-identical chairs of Alexander Burnett and his wife Katherine Gordon at Crathes Castle, which bear their initials in Roman capitals carved in relief with the date 1597 .

\section{POST-REFORMATION SCOTTISH LETTERING CARVED IN STONE}

The remaining Scottish Lettering carved in stone is almost entirely confined to the north-east. The shortage of surviving examples of lettering of any type, whether in secular or ecclesiastical roles, in the power centres of Scotland's central belt between the 1503 marriage and the postReformation period highlights both the turmoil of those decades and the destruction wrought during the following centuries. The official ecclesiastical use of Scottish Lettering appears to have ceased in the Aberdeen diocese soon after the death of Alexander Galloway in 1552. At court, classical Roman lettering soon came to replace the Scottish form, as can be seen on the arms of Mary of Guise, dated 1560, and Mary, Queen of Scots, dated 1565, today both in South Leith Parish Church. The links between both queens and France suggest that these carvings are the work of French masons. However, Scottish Lettering continued to be used after the Reformation, albeit at a lesselevated social level, on grave-slabs and in secular inscriptions. The few remaining examples in these roles are distributed beyond the north-east, raising the possibility that they were carved by one or more Aberdeen stonemasons versed in their local letterform, who may have been obliged to travel farther afield to seek fresh outlets for their skills under the new, more austere religious practices. 
In the fine part-Romanesque church of $\mathrm{St}$ Athernase at Leuchars is the grave-slab of Robert Carnegie who was the ambassador for both Mary of Guise and for her daughter the young Mary, Queen of Scots until his death in 1565. The slab bears a lengthy inscription in Scottish Lettering, carved in the later incised form seen on the Deskford and Cullen sacrament houses.

\section{Example 14: Grave-slab at the Howff Burial Ground, Dundee}

Among its last known applications in stone is the appearance of Scottish Lettering carved in relief on the distinctive perimeter or 'marginal' inscriptions of early Scottish horizontal graveslabs. The earliest such slab at the Howff burial ground at Dundee is that of 'THOMAS MEVR, BURGDE DE DVNDE'. It is dated 1577 (Thomson 2009: 73). (Grave ref: 226/2.)

\section{Example 15: Grave-slab at the Church of St Michael, Linlithgow}

The particular interest of this grave-slab, safely moved to within the church, is that it clearly displays the transition from the Scottish Lettering of the 16th century carved in 1589 to the classical
Roman form of 17th-century Scotland carved in 1615 on the same object (see Illus 10). The earlier marginal inscription around the perimeter and extending into the two uppermost lines reads, in raised Scottish lettering:

HERE LIES JHON [sic] FORREST OF MAGDALEN PROVOST OF THIS TOUN SVTEMLHO.DE.IT. THE VIII DAY OF MARCH ANO 1589.

Enclosed within this surround is the later inscription, also carved in relief on the same scale, but now in classical Roman capitals:

AS ALSO ROBERT STEWART HIS SONE IN LAW SUM TYME CORNE(T) OF HIS MAJESTIES GUARD 9HA DEIT. PRO PROVEST OF THIS TOUN YE LAST OF OCTOBER ANNO 1615.

\section{Example 16: The Entrance to Edzell Castle Garden}

The latest date on an original example of Scottish Lettering so far discovered is 1604, at Edzell Castle in Angus with the coat of arms over the archway leading into Scotland's first Renaissance garden. Along with this date it bears the initials of Sir David Lindsay and his second wife Dame

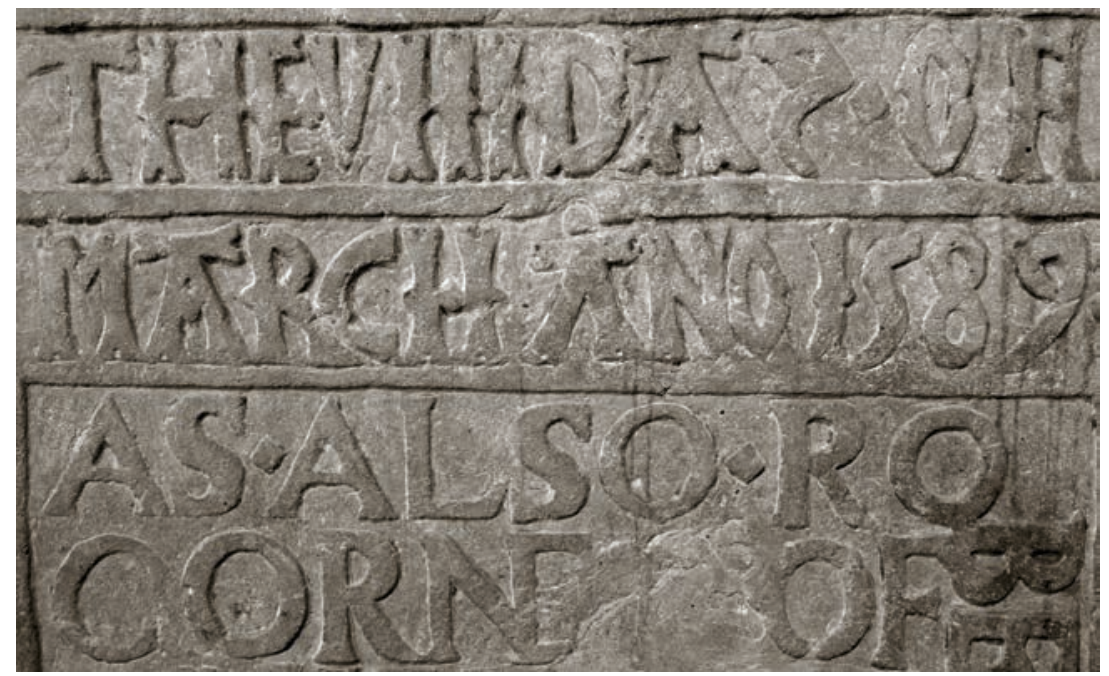

ILlus 10 Inscription detail; Grave-slab at St Michael's Church, Linlithgow, dated 1589 and 1615. (C) Aidan Harrison 
Isobel Forbes, just over a century after Scottish Lettering first appeared at the royal marriage in Edinburgh.

There are inevitably further examples of Scottish Lettering to be recorded, some of them disassociated from their original location. A typical example of such displacement, likely to date from 1531, is on one of the carved stones relocated when Edinburgh's Trinity Chapel was demolished and partly rebuilt as the Trinity Aisle in the 1870 s.

\section{BOOKS, PRINTING, COINS AND SEALS}

With very few exceptions, writing and printing of the period continued to use the Gothic style, although Scottish Lettering appeared briefly in the earliest native printed works. The text of the first book printed in Scotland, The Aberdeen Breviary, is entirely in Gothic lettering. However, because it was printed in 1510 on a press set up by King James IV and William Elphinstone, it follows that some of its capitals display the stylistic influence of Scottish Lettering. In contrast, Hector Boece's Scotorum Historia of 1527 is also printed in Gothic minuscule, but the capitals used on the title page are in the fully developed Roman form, reflecting the current use in Paris where it was made (Thomas 2013: 136, 164). The lettering used on Scottish coins changed from Gothic to Roman capitals towards the end of the reign of James IV, in contrast to the Gothic lettering used on royal seals which continued throughout the reign of James $\mathrm{V}$, while the new seal made for Mary, Queen of Scots 'takes us at one leap into the realm of Renaissance art-forms and the lettering on it is in good Roman capitals' (Stewart 1967: 260).

The absence of Scottish Lettering in such applications may be the result of little cultural or geographic connection between the local carvers of wood and stone and the more cosmopolitan world of printers and designers of coin dies and seals. The only inscription discovered in metal, engraved in an approximation of Scottish Lettering, is on the silver rim of the Bute, or Bannatyne mazer at the National Museum of
Scotland, which was added to the 14th-century maple-wood drinking vessel in the 1520s (NMS: Q.L.1979.11).

\section{LETTERING OUTSIDE SCOTLAND}

It is impossible to claim a particularly Scottish style of lettering without looking farther afield at the transition from Gothic writing to the classical Roman form as the influence of the Renaissance advanced. A few decades after the experiments with new letterforms in France, similar styles emerged fleetingly in Germany - where they survive on altars, goldsmith work and house inscriptions. The evidence again suggests that this transition occurred relatively quickly, without the emergence of any comparably distinct, consistent or lasting style, or any courtly application like that at the Edinburgh royal marriage. Because of their association with the Renaissance this range of letterforms is today known in Germany as fruhhumanistische capitalis - humanistic capitals (Wehking 2006: 2). Apart from the fact that their complexity made highly ornamented painted letterforms such as the Flemish 'raguly' style unsuited to carving, their demise was inevitably further hastened by the combined onslaught of the Reformation and the printing press.

Just as Scottish Lettering first appeared at the court of King James IV, the earliest comparable form discovered to date in England emerged a decade and a half later, also in kingly surroundings. It is the fine bronze inscription on the tomb of James IV's father-in-law, King Henry VII in Westminster Abbey (see Illus 11). The tomb, completed in $1518-19$ by Italian sculptor Pietro Torrigiano, is famous as the earliest major example of Renaissance design in England.

The authorisation for this unusual choice of letterform for such an important application in preference to both the Roman letters familiar to a classical Florentine sculptor and the Gothic style which was almost universal in England at the time has not been interrogated. Margaret Tudor's year of exile from Scotland in 1516-17 coincided with the construction of her father's tomb. The possibility that the Scottish queen, who was living at Westminster, influenced Torrigiano in adapting Scottish Lettering, perhaps from some 


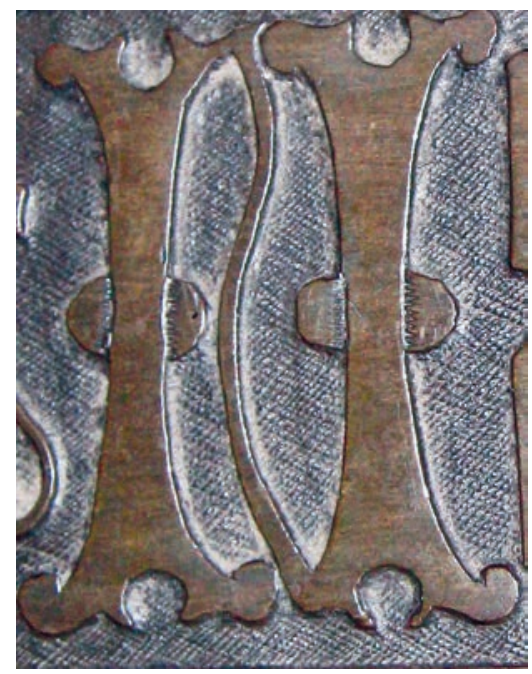

ILlus 11 Bronze letter 'N' on tomb of King Henry VII, Westminster Abbey. Photo by C Reynolds. (C) Dean and Chapter of Westminster

artefact in her possession, into this more etiolated, refined style warrants consideration. Equally late discussion and finalising of the details amidst the construction process had occurred just three years earlier in the same chapel over the tomb of her grandmother Margaret Beaufort (Geddes 2007: 85). In the 19th century, the ornate letters from Henry VII's tomb were imaginatively extrapolated into an entire alphabet in the same style by antiquarian Henry Shaw (Shaw 1999: 25).

The influence of Henry VII's Westminster tomb lettering is apparent in a small number of successive English applications. In similar fashion to the adoption of the lettering in Scotland from its courtly beginnings by leading churchmen, its subsequent choice by closely connected senior English clerics suggests that their inspiration may have sprung from Henry VII's tomb. Possible means of transmission include personal observation, word-of-mouth description, drawings or detailed written instructions such as the contract written in 1526 for smith Cornelyus Symondson to construct the iron railings around the tomb of Margaret Beaufort (Geddes 2007: 83). Hugh Ashton (d 1522), an executor of Margaret Beaufort, was deeply involved in the construction of her Westminster tomb. The iron railings of his own tomb at St John's College, Cambridge, by the same maker and almost identical to those of the Beaufort example, bear a lengthy iron inscription in Scottish Lettering (Geddes 2007: 89). Amongst his clerical appointments, Ashton had been an Archdeacon at Winchester from 1511 to 1519 under Bishop Richard Fox (c 1448-1528). Fox was Henry VII's greatest ally, prominent in the negotiations over the Treaty of Perpetual Peace between England and Scotland and the royal marriage. He was later a co-celebrant with the Bishop of Glasgow at the proxy marriage of Margaret Tudor to the Earl of Moray at Richmond Palace in January 1502. As a result of such associations, both with King Henry VII and his daughter, Margaret Tudor, it should not be surprising that incised lettering in a nearScottish form appears on Fox's presbytery screen of 1525 at Winchester Cathedral. As in Scotland, minor variations in the detail of the lettering reflect both the differing challenges posed by their materials and the whims of individual patrons and craftsmen. There is little evidence in England of the letterform appearing in significant applications later than the 1530s. This may be a further indication that the lettering was seen as a Catholic symbol which was rejected after the English Reformation, just as it was to suffer the same fate a generation later in Scotland.

\section{LATER REPRODUCTIONS OF SCOTTISH LETTERING}

Three centuries after its disappearance, the significance of Scottish Lettering was not entirely forgotten. Amongst the later restorations and alterations of Scotland's surviving structures of the 16th century are prominent examples which acknowledge and respect it as the appropriate native letterform of the period. During his major works on Edinburgh Castle in 1887-91 Hippolyte Blanc inserted a new stone bearing the fully developed Royal Arms of Scotland into the exterior wall of James IV's Great Hall. Its inscription 'IN DEFENSE' echoes the original Scottish Lettering. A stone panel dated 1555 
from the almshouse of the 'Incorporation of Masters and Mariners' at Trinity House, Leith, is carved in relief in Scottish Lettering. This is believed to be a Victorian reproduction copied from the original.

Dr William Kelly was responsible for major works at King's College Chapel, Aberdeen, during the late 1920s and early 1930s. An eminent historian and architect, he was in demand for the design and construction of memorials and monuments across Britain in the period following the First World War. He designed the Aberdeen University War Memorial which comprised a shrine within the ante-chapel to King's College Chapel to house the Roll of Service; the names of the fallen are carved on oak panels covering three of the walls. Dr Kelly was renowned for his lettering skills and had a particular regard for what he described as "fine capitals of the earlier part of the sixteenth century, half gothic, half renaissance ...' (Simpson 1949: 19).

For his gilded oak inscription carved in relief around the memorial, above the columns of names, Kelly chose to pay homage to those same capitals by emulating them in a similar style (see Illus 12). He was also responsible for the inscription in bronze on the Founder's Memorial, which incorporates fragments of Bishop Elphinstone's original tomb, at the east end of the chapel itself. Like those on Kelly's brass memorial to Hector Boece, first principal of the college (d 1536), set into the floor of the chapel, the lettering is again a sympathetic interpretation of the 16th-century Scottish form.

\section{CONCLUSION}

The first known use of Scottish Lettering at the royal wedding of 1503 was undoubtedly intended to be a striking, carefully considered emblem of a Scottish royal identity appropriate to that historic event.

The shortage of surviving inscriptions of any form in central Scotland from the following decades cannot rule out the possibility that the evidence for their existence has simply been erased everywhere except the northeast. However, its survival suggests that this letterform was in fact confined to the Aberdeen region, making it necessary to explore a possible explanation both for its isolation and for its primary adoption for religious applications. The most obvious argument is that the initial memory of its grand beginnings at the royal marriage, along with its use on the arms of James IV on the façade of King's College Chapel, inspired Aberdeen clerics such as Hector Boece and Alexander Galloway to perpetuate the local use of this distinctive symbol as a link with a much-loved monarch. Their mounting concerns amidst the religious turmoil of the following years may have seen them yearning for the security and support provided by James IV's well-recorded Catholic faith, exemplified by his frequent pilgrimages to Whithorn and Tain (Mackie 1958: 76, 94). Later, along with other specifically Scottish Catholic innovations, such as the sacrament houses with which it was closely associated, this lettering may have been a symbol employed by Alexander Galloway and others to maintain devotion to a particularly Scottish faith and its identity with the memory of their devout Catholic king. The later use of Scottish Lettering in English language rather than Latin inscriptions on the plain post-dissolution grave-slabs of civic leaders at Dundee and Linlithgow suggest that, despite those earlier Catholic associations, it

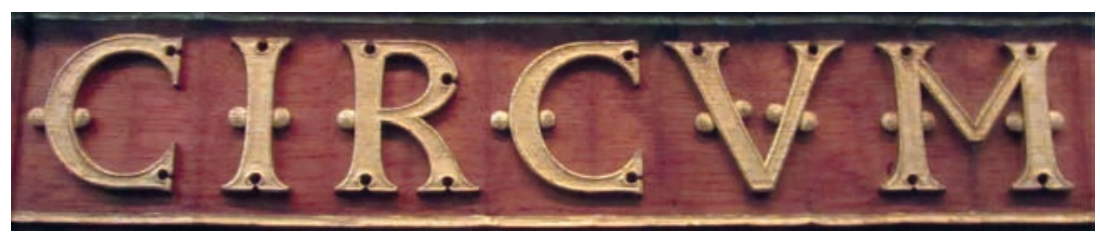

ILLus 12 Lettering by William Kelly at King's College War Memorial, Old Aberdeen. (C) Aidan Harrison 
eventually became an accepted style under the new religion.

The careful conservation and reproduction of Scottish Lettering by prominent architect/ historians such as Hippolyte Blanc and William Kelly in the restoration of 16th-century buildings of national importance - such as Edinburgh Castle, Linlithgow Palace and King's College Chapel, Aberdeen - are evidence of its acknowledgement by them as a significant mark of Scottish identity. It appears likely that the periodic cultural repression of symbols of the nation's Catholic past, along with wider evidence of Scotland's early Renaissance, saw it deliberately sidelined. Now, 500 years after its introduction and before the harsh climate further erodes yet more of its surviving examples, is perhaps time for a renewed appreciation of this lettering as a long-lapsed expression of the nationhood of the kingdom of Scotland. It must be emphasised not only that the conclusions at this stage are tentative but also that further examples of this letterform will inevitably come to light. As it uniquely persisted in Scotland for 100 years after its remarkable introduction at the court of King James IV in 1502-3, Scottish Lettering is today, surely, worthy of renewed national recognition.

\section{ACKNOWLEDGEMENTS}

The authors would like to thank the following: Gordon McNeill for access and information at Cullen Old Church. Neil Curtis and Caroline Dempsey for access to artefacts at the University of Aberdeen. Professor Jane Geddes at the University of Aberdeen for advice. Dr Rosie Harrison for guidance and focusing.

\section{REFERENCES}

Anon 1897 Gebetbuch Jakobs IV, von Schottland (facsimile edition). Graz, Austria: Akedemische Druk-u. Verlagsansalt.

Burnett, C J 2014 'The Original Armorials', in Geddes, J (ed.) King's College Chapel,
Aberdeen, 1500-2000, 2nd edn, 164-9. Leeds: Maney.

Campbell, I 2014 'Bishop Elphinstone's Tomb', in Geddes, J (ed.) King's College Chapel, Aberdeen, 1500-2000, 2nd edn, 149-60. Leeds: Maney.

Dennison, P, Ditchburn, D \& Lynch, M (eds) 2002 Aberdeen Before 1800. A New History. East Linton: Tuckwell Press.

Dunbar, J G 1999 Scottish Royal Palaces. East Linton: Tuckwell Press.

Eames, P 1977 Furniture in England, France and the Netherlands from the Twelfth to the Fifteenth Century. London: The Furniture History Society.

Fawcett, R 1994 The Architectural History of Scotland, 1371-1560. Edinburgh: Edinburgh University Press.

Fawcett, R 2013 Scottish Medieval Churches, Architecture \& Furnishings. Stroud: The History Press.

Fraser, G M 1913 The Bridge of Dee. Aberdeen: The Bon-Accord Press.

Geddes, J 2007 'Cornelyus Symondson and the tomb railings of Lady Margaret Beaufort', in Marks, R (ed.) Late Gothic England: Art and Display, 85. Donington: Shaun Tyas.

Geddes, J 2014 'The wooden furnishings of Bishop Elphinstone's Chapel. Part 3: The Organ, the 'Ambo' and the Pulpitum', in Geddes, J (ed.) King's College Chapel, Aberdeen, 1500-2000, 2nd edn, 104-26. Leeds: Maney.

Geddes, J 2016 'Piping Pigs and Mermaid Groping: Six Carved Panels from Fetteresso', in Geddes, J (ed.) Medieval Art, Architecture and Archaeology in the Dioceses of Aberdeen and Moray, 158-83. Abingdon: Routledge.

Gray, N 1986 A History of Lettering. Oxford: Phaidon.

Harrison, A 2012 'A Small Scottish Chest', Regional Furniture 2012: 1-22.

Harrison, A 2015 'A Small Scottish Chair', Regional Furniture 2015: 1-13.

Heal, F 2003 Reformation in Britain and Ireland. Oxford: Oxford University Press.

Higgitt, J 1988 'Klebister, Shetland. An armorial stone and an archdeacon's tend barn', Post Medieval Archaeology 22: 1-20. 
Higgitt, J 2014 'The Foundation Inscription', in Geddes, J (ed.) King's College Chapel, Aberdeen, 1500-2000, 2nd edn, 66-73. Leeds: Maney.

Holmes, S M 2015 Sacred Signs in Reformation Scotland, 1488-1590. Oxford: Oxford University Press.

Kelly, W 1934 'Carved Oak from St Nicholas Church, Aberdeen', Proc Soc Antiq Scot 68: 355-66.

Kren, T \& McKendrick, S 2003 Illuminating The Renaissance. London: Royal Academy of Arts.

MacCannell, D 2014 'The wooden furnishings of Bishop Elphinstone's Chapel. Part 2: The Misericords', in Geddes, J (ed.) King's College Chapel, Aberdeen, 1500-2000, 2nd edn, 95101. Leeds: Maney.

MacDonald, A 2003 'Princely culture in Scotland under James III and James IV', in MacDonald, A \& Vanderjagt, A J (eds) 2003 Princes and Princely Culture, 1450-1650, Vol 1. Leiden: Brill.

Mackie, R L 1958 King James IV of Scotland. Edinburgh: Oliver \& Boyd.

Macmillan, D 2000 Scottish Art 1460-2000. Edinburgh: Mainstream Publishing.

McRoberts, D \& Holmes, S M (eds) 2012 Lost Interiors: Rhind Lectures 1969-70. Edinburgh: Aquhorties Press.

Norton, E 1994 'Medieval Floor Tiles in Scotland', in Higgitt, J (ed.) Medieval Art and Architecture in the Diocese of St Andrews, 137-73. London: Routledge.

Oram, R 2016 'The Medieval Church in the Dioceses of Aberdeen and Moray', in Geddes, J (ed.) Medieval Art, Architecture and Archaeology in the Dioceses of Aberdeen and Moray, 16-33. Abingdon: Routledge.

Paul, J B 1901 The Accounts of the Lord High Treasurer, Vol 2. Edinburgh: HM General Register House.

Pflughaupt, L 2007 Letter by Letter. New York: Princeton Architectural Press.

Richardson, J S 1927 'The Campbell of Lerags Cross at Kilbride, near Oban', Proc Soc Antiq Scot 61: 143-62.
Rosie, A \& Ramsay, L 2001-2 'The Treaty of Perpetual Peace', Annual Report of the Keeper of the Records of Scotland: 65-6.

Ross, L 2014 Language in the Visual Arts: The Interplay of Text and Imagery. Jefferson, USA: McFarland \& Co.

Shaw, H (ed.) 1999 Medieval Alphabets and Decorative Devices of the Middle Ages. New York: Dover Publications Inc.

Simpson, G G 2009 Scottish Handwriting 11501650. Edinburgh: John Donald.

Simpson, S 2014 'The Choir Stalls and Rood Screen', in Geddes, J (ed.) King's College Chapel, Aberdeen, 1500-2000, 2nd edn, 7494. Leeds: Maney.

Simpson, W D (ed.) 1949 A Tribute Offered by The University of Aberdeen to the Memory of William Kelly, LL.D, A.R.S.A. Aberdeen: Aberdeen University Press.

Small, J W 1878 Scottish Woodwork of the 16th and 17th Centuries. Edinburgh: Douglas.

Smeyers, M 1999 Flemish Miniatures from the 8th to the 16th Century. Turnhout, Belgium: Brepols.

Stewart, I H 1967 'Some Scottish Ceremonial Coins', Proc Soc Antiq Scot 98: 254-75.

Swarbrick, L 2016 'Patronage of the Collegiate Church at Cullen', in Geddes, J (ed.) Medieval Art, Architecture and Architecture in the Dioceses of Aberdeen and Moray, 121-39. Abingdon: Routledge.

Thirion, J 1999 Le Mobilier du Moyen Age et de la Renaissance. Dijon, France: Editions Faton.

Thomas, A 2013 Glory and Honour. The Renaissance in Scotland. Edinburgh: Birlinn.

Thomson, G 2009 Inscribed in Remembrance. Dublin: Wordwell Ltd.

Waldie, G 1868 The History of Linlithoow. Linlithgow: self-published.

Wehking, S 2006 Die Inschriften des Landkreises Göttingen. Weisbaden: Reichert.

\section{DOCUMENTARY SOURCES}

PRO E39/81 Similar ratification of Scots. Doct. 92 (18) PRO E39/81 1502, The National Archives, Kew. 
PRO E39/58 Similar ratification of Scots. Doct. 93 (12) PRO E39/58 1502, The National Archives, Kew.

NAS SP6/31 Ratification by King Henry VII of indenture on treaty of perpetual peace between England and Scotland. At Westminster. Signed by the King. SP6/31 1502, National Records of Scotland, Edinburgh.

\section{ELECTRONIC SOURCES}

Stevenson, J \& Davidson, P 2009 'Ficino in Aberdeen: The Continuing Problem of the Scottish Renaissance', Journal of the Northern Renaissance 1. http://northernrenaissance.org. Accessed 15 March 2018. 